\title{
Pkm Pendampingan Pelatihan Pengolahan Wadi Pindang Pada Ibu-Ibu Rumah Tangga Di Jalan Hiu Putih Kota Palangka Raya
}

\author{
Wahyu Edy Setiawan ${ }^{1}$ Luluk Tri Harinie ${ }^{2}$ Syahril Uhing ${ }^{3}$ Abdul Rahmat ${ }^{4}$ \\ ${ }^{1}$ Staf Pengajar Program Magister PLS PPs UPR; Email: Wahyu.setiawan@ fkip.upr.ac.id; HP \\ 081334488331 \\ ${ }^{2}$ Staf Pengajar Program Magister PLS PPs UPR. \\ ${ }^{3}$ Mahasiswa Program Magister PLS PPs UPR. \\ ${ }^{4}$ Dosen Universitas Negeri Gorontalo
}

Received: 02 Oktober 2020; Revised: 21 November 2020; Accepted: 28 Desember 2020 DOI: http://dx.doi.org/10.37905/aksara.7.1.123-136.2021

\begin{abstract}
Abstrak
Pengabdian kepada Masyarakat ini tentang Pendampingan Pelatihan Pengolahan Wadi Pindang pada ibu-ibu Rumah Tangga di Jalan Hiu Putih, Kota Palangka Raya, adalah salah satu kegiatan ABDIMAS Program Pascasarjana, Universitas Palangka Raya yang memanfaatkan ikan patin untuk dijadikan Wadi, makanan fermentasi tradisional yang sehat dan bergizi dar Kalimantan Tengah. Wadi ini diolah secara alami dan tidak menggunakan bahan pengawet. Rata-rata penyimpanan wadi agar siap saji minimal dilakukan selama 7 hari dan kemudian dikemas rapi dalam boksboks siap jual melalui media online sebagai salah satu media bantu pemasaran ke konsumen di saat pandemi Covid 19. Mitra Bina Keluarga Remaja sangat berperan dalam memberikan motivasi dan semangat juang tinggi kepada ibu-ibu rumah tangga di lingkungan Jalan Hiu Putih agar selalu survive dan semangat.

Luaran dari kegiatan Pengabdian kepada Masyarakat (PkM) ini berupa publikasi jurnal, publikasi media massa, dan dapat dijadikan sebagai salah satu referensi mata kuliah, diantaranya adalah: Kewirausahaan dan Social Entrepreneurship, Andragogi dalam Pendidikan Masyarakat, Kajian Pemberdayaan Masyarakat di Daerah Gambut dan Aliran Sungai (DAS).
\end{abstract}

Kata Kunci: Pendampingan, Pelatihan, Wadi Pindang, Ibu-ibu Rumah Tangga

\section{PENDAHULUAN}

Mewabahnya Covid 19 dewasa ini membuat banyak orang melakukan inovasi dalam berbagai bidang demi bisa memenuhi kebutuhan sehari-hari. Pembatasanpembatasan yang dilakukan agar wabah ini tidaklah meluas membuat aktifitas seharihari yang biasa di lakukan menjadi agak terganggu, misalnya: orang tidak boleh berkumpul lama dalam satu tempat, selalu menggunakan masker, dan lain sebagainya. Akibat dari itu semua penghasilan yang biasanya lebih di terima oleh masyarakat menjadi sangat berkurang, untuk itu beberapa masyarakat melakukan inovasi dan modifikasi agar dapat survive di tengah wabah saat ini.

Salah satunya adalah di Jalan Hiu Putih, Kota Palangka Raya, beberapa ibuibu di sekitar jalan tersebut berinisiatif melakukan inovasi-inovasi agar dapat 
membantu suami sehingga kebutuhan ekonomi tetap dapat berjalan. Ibu-ibu rumah tangga pada daerah tersebut melakukan inovasi dengan memanfaatkan potensi yang ada di sekitarnya, yaitu mengolah ikan patin menjadi wadi pindang. Kalimantan Tengah sangat terkenal dengan lahan gambutnya yang memiliki potensi ekonomi diberbagai sektor yakni pertanian, perikanan, peternakan, perkebunan, kehutanan, wisata dan pertambangan. Potensi tersebut masih belum dimaksimalkan oleh masyarakat sebagai sumber usaha dalam meningkatkan ekonomi masyarakat.

Sebagai bentuk Tri Dharma Perguruan Tinggi dalam melakukan pendampingan pada kegiatan tersebut dengan memberikan penguatan, motivasi, penggunaan media, dan entrepreneurship kepada ibu-ibu rumah tangga di Jalan Hiu Putih tersebut. Langkah ini diambil agar ibu-ibu rumah tangga tesebut selalu survive dan tidak gampang menyerah dalam menghadapi keadaan yang terjadi saat ini. Pendampingan ini menggunakan pendekatan pembelajaran partisipatif. Knowles dalam Mulyasa (2003: 89) menyebutkan indikator pembelajaran partisipatif adalah: a) adanya keterlibatan emosional dan mental peserta didik; b) adanya kesediaan peserta didik untuk memberikan kontribusi dalam pencapaian tujuan; dan c) dalam kegiatan belajar terdapat hal yang menguntungkan peserta didik. Pengembangan pembelajaran partisipatif dilakukan dengan prosedur berikut sebagai berikut: a) menciptakan suasana yang mendorong peserta didik siap belajar; b) membantu peserta didik menyusun kelompok, agar siap belajar dan membelajarkan; c) membantu peserta didik untuk mendiagnosis dan menemukan kebutuhan belajarnya; d) membantu peserta didik menyusun tujuan belajar; e) membantu peserta didik merancang pola-pola pengalaman belajar; f) membantu peserta didik melakukan kegiatan belajar; dan g) membantu peserta didik melakukan evaluasi diri terhadap proses dan hasil belajar.

Ife dan Tesoriero (2008) mengatakan bahwa pengembangan masyarakat harus selalu berupaya untuk memaksimalkan partisipasi dengan tujuan membuat setiap orang dalam masyarakat terlibat secara aktif dalam proses dan kegiatan masyarakat serta untuk menciptakan kembali masa depan masyarakat dan individu yang lebih baik. Menurut Sudjana, (2010:40) pembelajaran partisipatif adalah kegiatan pembelajaran di mana semua pihak, termasuk pendidik dan peserta didik, terlibat secara aktif dalam setiap kegiatan pembelajaran. Keikutsertaan peserta didik itu diwujudkan dalam tiga tahapan kegiatan pembelajaran yaitu tahap perencanaan program (program planning), pelaksanaan (program implementtion), dan penilaian (program evaluation) kegiatan pembelajaran. Sejalan dengan itu Knowles (1977: 38) menyatakan bahwa pembelajaran partisipatif pada hakikatnya melibatkan warga belajar yang tergolong pada usia dewasa dan konsep pembelajaran yang relevan untuk digunakan dalam pembelajaran partisipatif adalah pembelajaran yang sesuai dengan kondisi, dan karakteristik orang dewasa, yakni pembelajaran yang berlandaskan pendekatan andragogi yaitu, seni dan ilmu membantu orang dewasa belajar. 
Proses pemberdayaan perempuan melalui program pendidikan luar sekolah pada dasarnya harus diawali dengan penyadaran masyarakat sasaran. Langkah penyadaran dimaksudkan untuk memungkinkan masyarakat mampu mengidentifikasi kebutuhan dan merumuskan tujuan belajar atau tujuan hidupnya. Proses pemberdayaan tanpa diawali dengan penyadaran kelompok sasaran, maka kemungkinan akan menghadapi hambatan, baik oleh masayarakar maupun oleh sumber belajar atau agen perubahan. Anwar, (2007: 88), mengemukakan bahwa:

bidang keterampilan merupakan primadona bagi perempuan pedesaan. Keterampilan seperti menjahit, kerajinan tangan, dan beberapa industri rumah tangga, jenis keterampilan yang tidak mengganggu kodrat perempuan, tidak menyulitkan untuk menggunakan busana muslimah, dan tidak mengharuskan bergaul dengan laki-laki tanpa muhrimnya. Singkatnya, keterlibatan perempuan dalam pekerjaan keterampilan tersebut dapat meningkatkan peran perempuan dan menambah wawasan perempuan yang dapat lebih meningkatkan kualitas hidup dan harmoni dalam rumah tangganya.

Kegiatan Pengabdian kepada Masyarakat ini dilaksanakan pada Kelurahan Bukit Tunggal, Kota Palangka Raya tepatnya pada Jalan Hiu Putih.

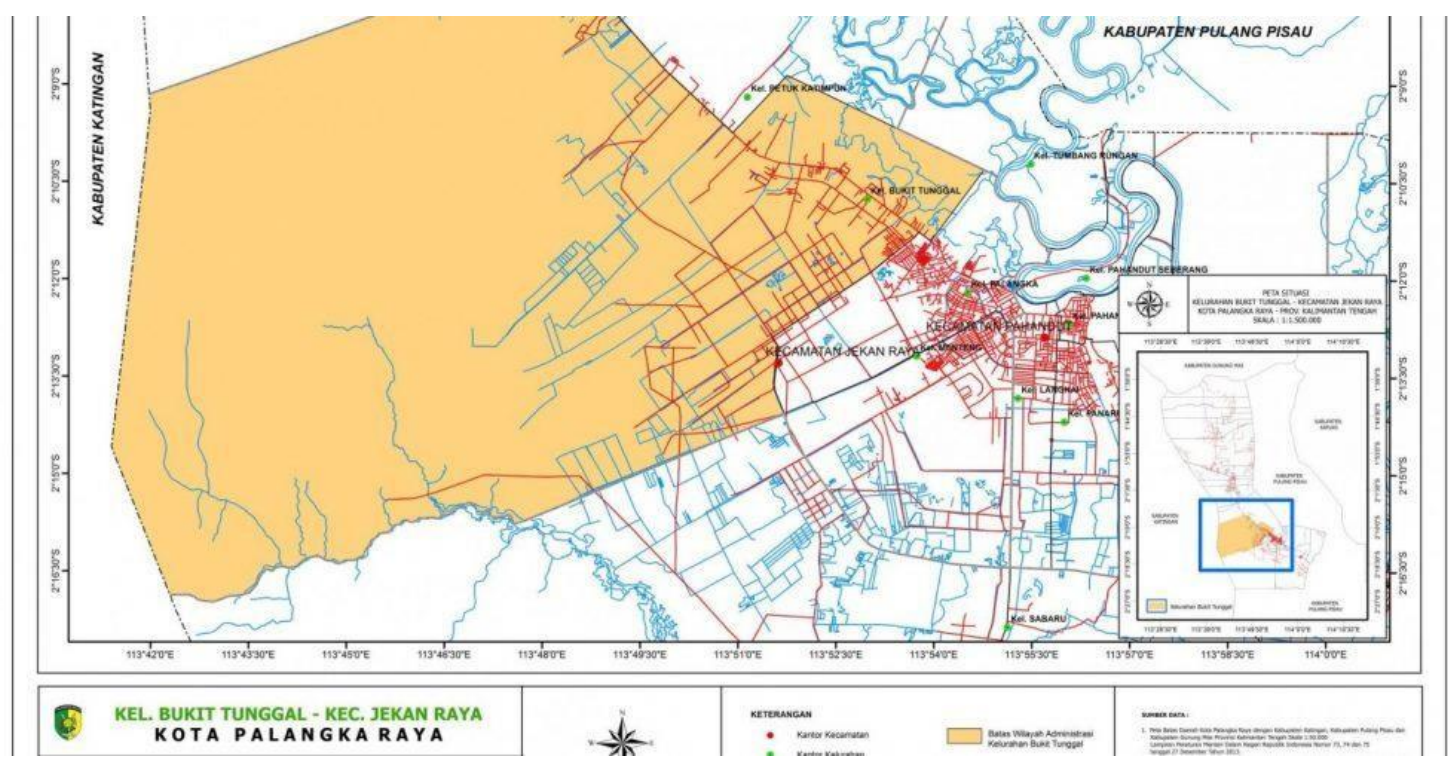

Gambar 1. Peta Lokasi Kegiatan

Berdasarkan paparan di atas, tim ABDIMAS tertarik melakukan pendampingan kepada masyarakat ibu-ibu rumah tangga di Jalan Hiu Putih melalui program pengabdian masyarakat dengan judul "PkM Pendampingan Pelatihan Pengolahan Wadi Pindang pada ibu-ibu Rumah Tangga di Jalan Hiu Putih, Kota Palangka Raya" 
Permasalahan Mitra

Permasalahan prioritas yang telah disepakati bersama mitra adalah:

1. Motivasi dari ibu-ibu rumah tangga peserta pelatihan wadi pindang sangat rendah dan rentan tidak dapat bertahan

2. Diperlukan pendampingan sebagai penguatan bagi ibu-ibu rumah tangga dari tim Pengabdian kepada Masyarakat.

3. Belum memiliki pengetahuan yang baik tentang pemanfaatan penggunaan media dan teknik pemasaran menggunakan sosial media.

\section{METODE PELAKSANAAN}

\section{Metode Pelaksanaan}

Prosedur kerja/mekanisme pelaksanaan kegiatan adalah:

a. Perencanaan dan persiapan. Menentukan dan menyusun jadwal pertemuan bersama mitra; menyiapkan alat dan bahan.

b. Tindakan. Implementasinya melalui ceramah, pendampingan, diskusi bersama mitra dan warga binaan.

c. Melakukan pelatihan pembuatan wadi pindang patin dan pemanfaatan media sosial sebagai alat bantu pemasaran.

Solusi bagi Pendampingan Pelatihan Pengolahan Wadi Pindang pada ibu-ibu Rumah Tangga

Partisipasi merupakan suatu bagian penting dari pemberdayaan dan penumbuhan kesadaran. Mendorong partisipasi adalah suatu proses yang membutuhkan keterampilan, dan pemantauan secara terus menerus tentang dampaknya terhadap rakyat mengenai partisipasi mereka dalam kegiatan-kegiatan pengembangan masyarakat. Partisipasi harus menghasilkan keluaran positif, baik dari segi membangun kepercayaan pribadi maupun dari segi kontrol terhadap lingkungan seseorang dan kemampuan untuk mempengaruhi keputusan yang akan memberi dampak pada kehidupan orang. Davis dalam Sastropoetro (1988:16-18) menyatakan untuk dapat melaksanakan pembelajaran partisipasi secara efektif adalah sebagai berikut:

a) adanya waktu; b) kegiatan partisipasi memerlukan dana perangsang secara terbatas; c) subyek partisipasi hendaklah berkaitan dengan organisasi dimana individu yang bersangkutan itu tergabung atau sesuatu yang menjadi perhatiannya;

d) partisipan harus memiliki kemampuan untuk berpartisipasi dalam arti kata yang bersangkutan memiliki pemikiran dan pengalaman yang sepadan; e) kemampuan untuk melakukan komunikasi timbal balik; f) bebas melaksanakan peran serta sesuai dengan persyaratan yang telah ditentukan; dan g) adanya kebebasan dalam kelompok, tidak adanya pemaksaan atau penekanan.

Knowles (1984: 44 - 46), menjelaskan bahwa:

pembelajaran orang dewasa dirancang melibatkan sejumlah pandangan yang mengakui keterkaitan dengan kematangan pebelajar dewasa, yaitu bahwa: a. belajar orang dewasa berpusat pada masalah (problem - centered) bukan 
berpusat pada isi pelajaran (content-centered); b. belajar orang dewasa harus memungkinkan dan mendorong partisipasi aktif pebelajar; c. belajar orang dewasa mendorong pebelajar melibatkan pengalaman masa lalu ke dalam proses, untuk menilai kembali pengalaman itu di dalam data dan masalahmasalah yang baru; d. iklim belajar harus kolaboratif (instruktor dengan pebelajar, dan pebelajar dengan pebelajar); e. perencanaan belajar dilakukan sebagai aktivitas bersama antara pebelajar dengan instruktor; f. evaluasi dilakukan sebagai aktivitas bersama antara pebelajar dengan instruktor; g. evaluasi diarahkan pada penilaian kembali tentang kebutuhan dan minat, dan untuk merancang ulang kembali aktivitas pembelajaran yang baru; dan $\mathrm{h}$. aktiviitas belajar orang dewasa adalah pengalaman bukan "pemindahan dan penyerapan" (not "transmittal and absorption").

Ife (1995:27) menyarankan tiga strategi dasar pemberdayaan untuk mengembangkan masyarakat yang berdaya yaitu:

a. Pemberdayaan melalui kebijakan dan perencanaan, dilakukan dengan merubah struktur dan lembaga-lembaga yang ada agar terjadi akses yang sesuai dengan sumber-sumber dan pelayanan-pelayanan, serta munculnya partisipasi dalam kehidupan masyarakat;

b. Pemberdayaan melalui aksi sosial dan politik, menekankan kepada pentingnya pejuangan dan perubahan politik untuk meningkatkan keberdayaan yang lebih efektif, dimana masyarakat dapat dilibatkanunuk melakukan aksi-aksi langsung; dan

c. Pemberdayaan melalui pendidikan dan penyadaran, menekakan pada pentingnya proses pendidikan, sehingga pihak yang diberdayakan memperoleh kemampuan-kemampuan. Cara ini dilakukan dengan memberikan pengetahuan akan berbagai hal yang menjadi kendala baik strutural maupun kendala-kendala kemasyarakatan, juga memberikan keterampilan untuk berkarya secara efektif untuk menuju perubahan. Kegiatan pembelajaran keterampilan kejuruan (vocational skills) sebagai proses pemberdayaan perempuan melalui pembelajaran partisipatif dan pendekatan andragogi dilakukan melalui berbagai tahapan, dimulai dari proses penyadaran dalam bentuk dialog dengan anggota masyarakat terutama anggota kelompok sasaran, perencanaan pembelajaran, pengorganisasian, pelaksanaan, penilaian, dan pengembangan pembelajaran.

Pemanfaatan social media dapat berimbas positif bagi sebuah produk. Penggunaan media sosial digunakan oleh masyarakat dalam melakukan banyak aktivitas mulai dari entertainment, melakukan bisnis, mencari info atau aktivitas lainnya. Whatsapp sebagai salah satu media sosial yang berbasis chat, networking yang digunakan untuk berkomunikasi, sharing dokumen, foto, video call dan call yang menggunakan jaringan internet. Maoyan (2014) menyatakan bahwa pemasaran melalui media sosial akan memengaruhi faktor eksternal yang mempengaruhi persepsi konsumen akan sebuah produk, yang kemudian akan mempengaruhi minat beli konsumen. 
Gunawan dan Huarng (2015) mengemukakan bahwa interaksi sosial dan resiko yang dipersepsikan melalui media sosial berpengaruh terhadap minat beli konsumen. Media sosial menurut Kotler dan Keller (2016) digunakan sebagai alat komunikasi pemasaran untuk meningkatkan kesadaran konsumen terhadap produk, meningkatkan image produk dan berakhir pada peningkatan penjualan. Selaras dengan itu, Kshetri dan Jha (2016) mengemukakan bahwa penggunaan media sosial terhadap suatu brand merupakan suatu komunikasi yang menyampaikan informasi mengenai pemasok dan penggunaan produk kepada konsumen melalui online shopping menggunakan teknologi berbasis internet seperti facebook, twitter, instagram, whatsapp dan berbagai media sosial lainnya.

Komunikasi pemasaran melalui media sosial menurut Hauer (dalam Arief dan Millianyani, 2015) dapat dinilai melalui 4C, yaitu context, communication, collaboration, dan connection. Context adalah cara seseorang membentuk suatu cerita melalui penggunaan bahasa dan isi pesan. Communication adalah cara berbagi cerita membuat seseorang mendengar, merespon, dan tumbuh sehingga orang menjadi nyaman dan pesan tersampaikan kepada orang yang dituju. Collaboration adalah kerja sama antara akun dengan pengguna media sosial yang bertujuan membuat hal menjadi lebih baik, lebih efisien, dan lebih efektif. Connection adalah cara mempertahankan dan terus mengembangkan hubungan yang telah dilakukan.

Merujuk pada permasalahan yang telah dipaparkan diatas melalui hasil wawancara dan diskusi awal bersama ibu-ibu rumah tangga di Jalan Hiu Putih dalam kaitannya agar dapat selalu survive maka tim pengabdian kepada masyarakat melakukan pendampingan dan pengenalan penggunaan media sehingga promosi dari hasil olahan ikan patin wadi pindang dapat dinikmati oleh masyarakat Kota Palangka Raya. Pendekatan yang perlu ditempuh dalam pemberdayaan menurut Kindervatter dalam Suharto (2006:43) adalah: a. Need oriented, yaitu suatu pendekatan yang berorientasi pada kebutuhan individu; b. Endogenous, yaitu pendekatan yang berorientasi pada kondisi dan kenyataan yang berlangsung di masyarakat setempat; c. Self reliance, yaitu pendekatan dengan berorientasi pada terciptanya rasa mampu diri, percaya pada diri sendiri dan mandiri; dan d. Ecolological sound, yaitu suatu pendekatan yang tidak melupakan aspek lingkungan.

Melalui aplikasi chatting media sosial whatsapp ibu-ibu rumah tangga mitra ABDIMAS memiliki kemampuan dan keterampilan dalam membuat interaktif digital promosi bagi produk usahanya yang sesuai dengan pasar saat ini. Kreatifitas dari ibu- ibu rumah tangga mitra ABDIMAS melalui aplikasi chatting pada media sosial whatsapp membuat gambar dan kata-kata yang lugas, pesan tersampaikan, tidak bertele-tele, mudah dipahami sehingga dapat menarik masyarakat untuk membaca dan membeli produk yang ditawarkan.

\section{METODE PENGABDIAN}

Komponen yang saling berhubungan untuk berhasilnya belajar orang dewasa dapat diringkas melalui diagram yang digambarkan sebagai berikut: 


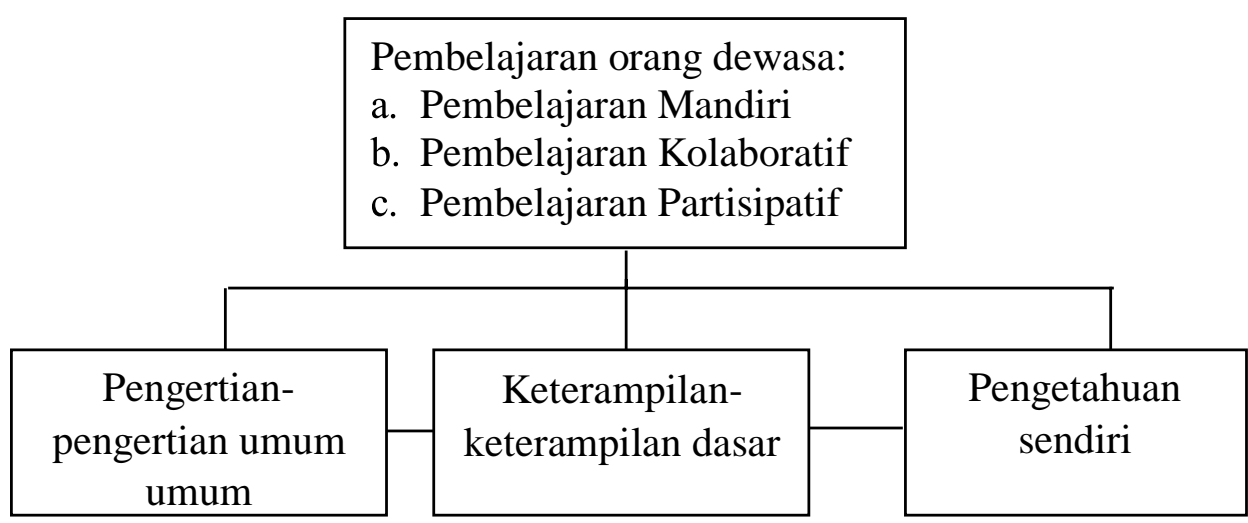

Gambar 2. Komponen Hasil Belajar

\section{Evaluasi Pelaksanaan}

Strategi dan pendekatan dalam evaluasi pemberdayaan Kindervatter (Suharto, 2006:44) menyebutkan beberapa karakter, yaitu:

a. Community Organization, adalah satu karakter yang mengacu kepada tujuan guna mengaktifkan masyarakat dalam rangka meningkatkan dan mengubah keadaan sosial ekonomi masyarakat. Struktur yang digunakan dalam mencapai tujuan tersebut adalah dengan mengorganisasikan kelompok-kelompok yang telah ada dan dengan mengadakan penggabungan dengan atau reorganisasi kelompok-kelompok tersebut. Selain dari pada itu juga dilakukan pengembangan kelompok-kelompok serta struktur yang sudah ada; b. Self Management and Collaboration, berorientasi kepada upaya penyamaran atau pembagaian wewenang di dalam hubungan kerja atau dalam suatu kegiatan. Untuk itu diperlukan adanya struktur organisasi yang mendukungannya serta upaya-upaya untuk memperkecil adanya perpedaan status, antara lain dengan pembagian peran. Metoda dan proses pembelajaan dilakukan melalui saling membelajaran, pengambilan keputusan secara mufakat; c. Participatory Approach, yang menekankan adanya keterlibatan setiap anggota masyarakat (warga belajar atau masyarakat) dalam seluruhan kegiatan; dan d. Education for Justice, yang memfokuskan kepada terciptanya situasi yang memberikan kemungkinan bagi seseorang untuk tumbuh dan berkembang dalam peningkata kemampuan analitisnya serta mendorong untuk ikut berperan. Metoda yang digunakan antara lain adalah dengan menciptakan memunculkan permasalahan, menganalisis kesahan-kesalahan atau konflikkonflik dari segi yang positif. Dalam keterkaiatannya tersebut, masyarakat sebagai warga belajar terlebih dahulu berperan sebagai sumber pengalaman atau pengetahuan bagi warga belajar lainnya dan mengambil bagian dalam kepemimpinan. 


\section{HASIL DAN LUARAN YANG DICAPAI Hasil PkM}

Kegiatan pertama di tempat pengolahan wadi ikan adalah mempersiapkan bahan- bahan dan alat-alat yang diperlukan yaitu: kompor, wajan, blender, sendok besar, baskom,stofles, timbangan, ikan patin segar, pisau, garam, gula merah, beras putih. Peserta dari kegiatan ini berjumlah 5 orang ibu-ibu rumah tangga di sekitar Jalan Hiu Putih.

Kegiatan ini akan dilakukan 2 tahap, tahap 1 di hari pertama diawali dengan membersihkan ikan patin menggunakan air bersih yang mengalir kemudian ditiriskan. Proses selanjutnya adalah menyiapkan bahan utama lumu, yang terdiri beras, garam, gula merah dan timbangan. Ketiga bahan tadi kemudian ditimbang.
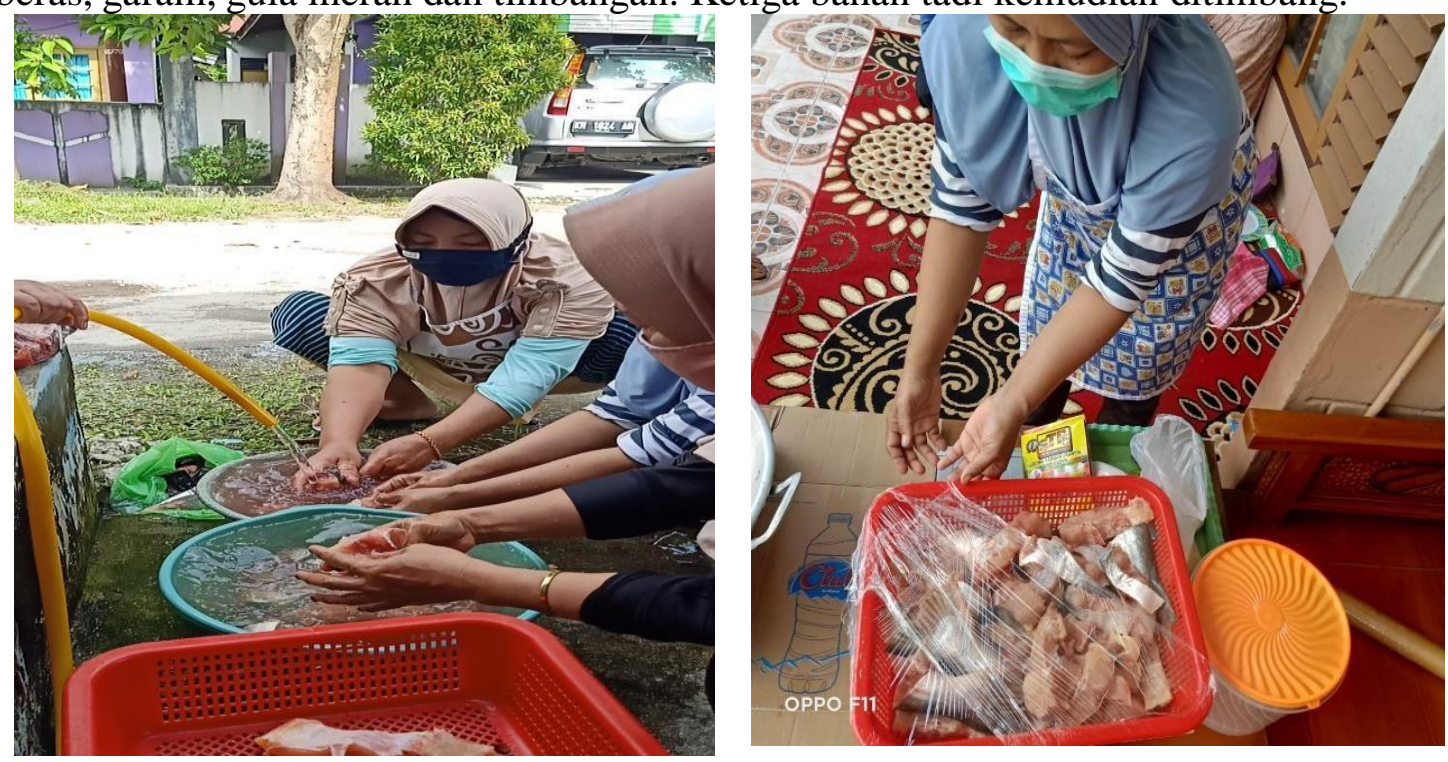

Langkah selanjutnya adalah cuci beras yang telah ditimbang tadi sampai bersih dengan air mengalir dan setelah itu ditiriskan. Proses selanjutnya adalah memberi garam pada ikan patin segar yang telah di cuci tadi sambal diaduk-adul menggunakan tangan agar garam tercampur dengan sempurna. 

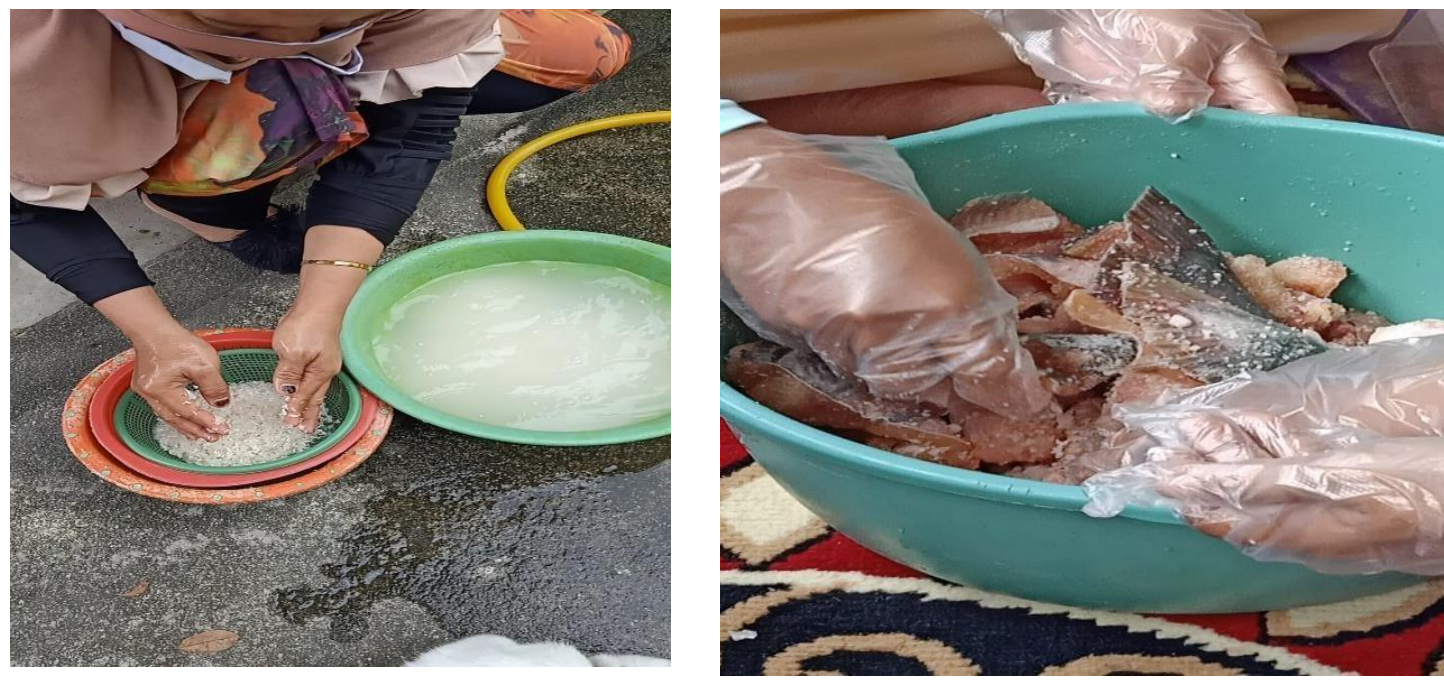

Setelah dilakukan penggaraman maka proses selanjutnya adalah memasukkan gula merah ke dalam adonan ikan patin dan di aduk agar bercampur dengan garam. Kegiatan berikutnya adalah menyangrai beras di atas kompor hingga matang dan berwarna kecoklatan.
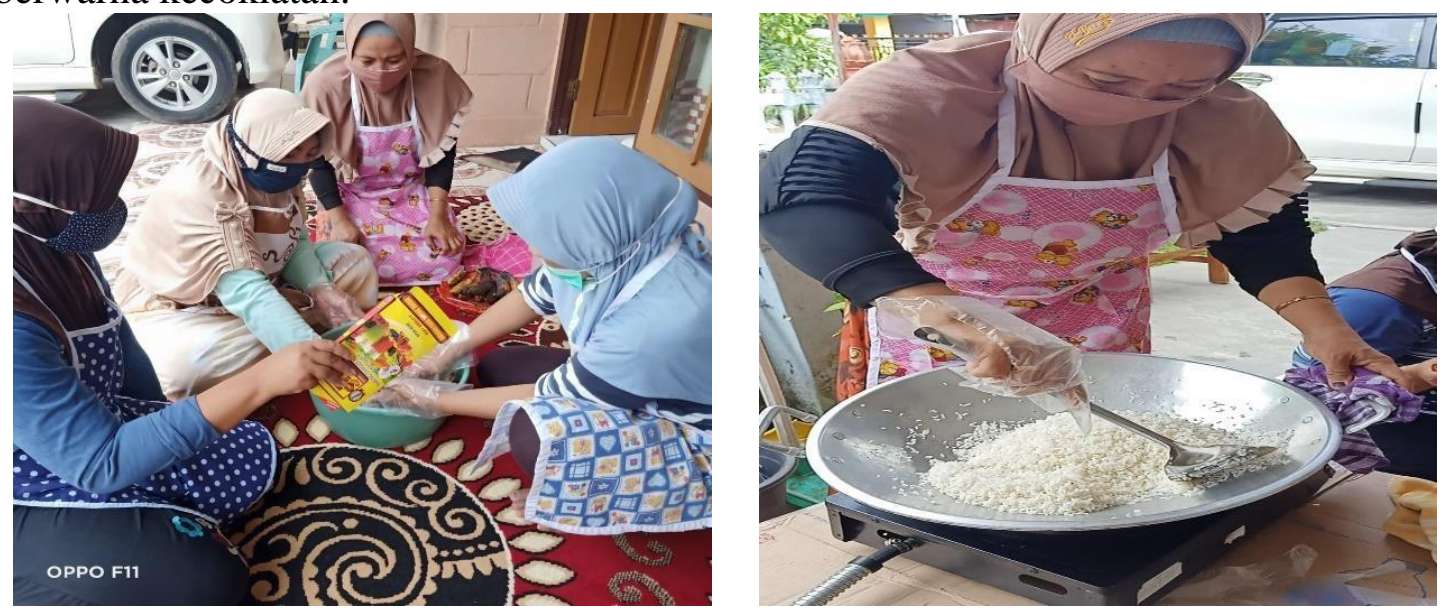

Sembari menunggu beras yang di sangria hingga berwarna kecoklatan, proses selanjutnya adalah memasukkan ikan patin yang telah di garami dan di berikan gula merah ke dalam toples dan tutup rapat serta didiamkan selama 12 jam. Kegiatan tahap 1 ini telah selesai dilakukan dan akan dilanjutkan kembali besok. 

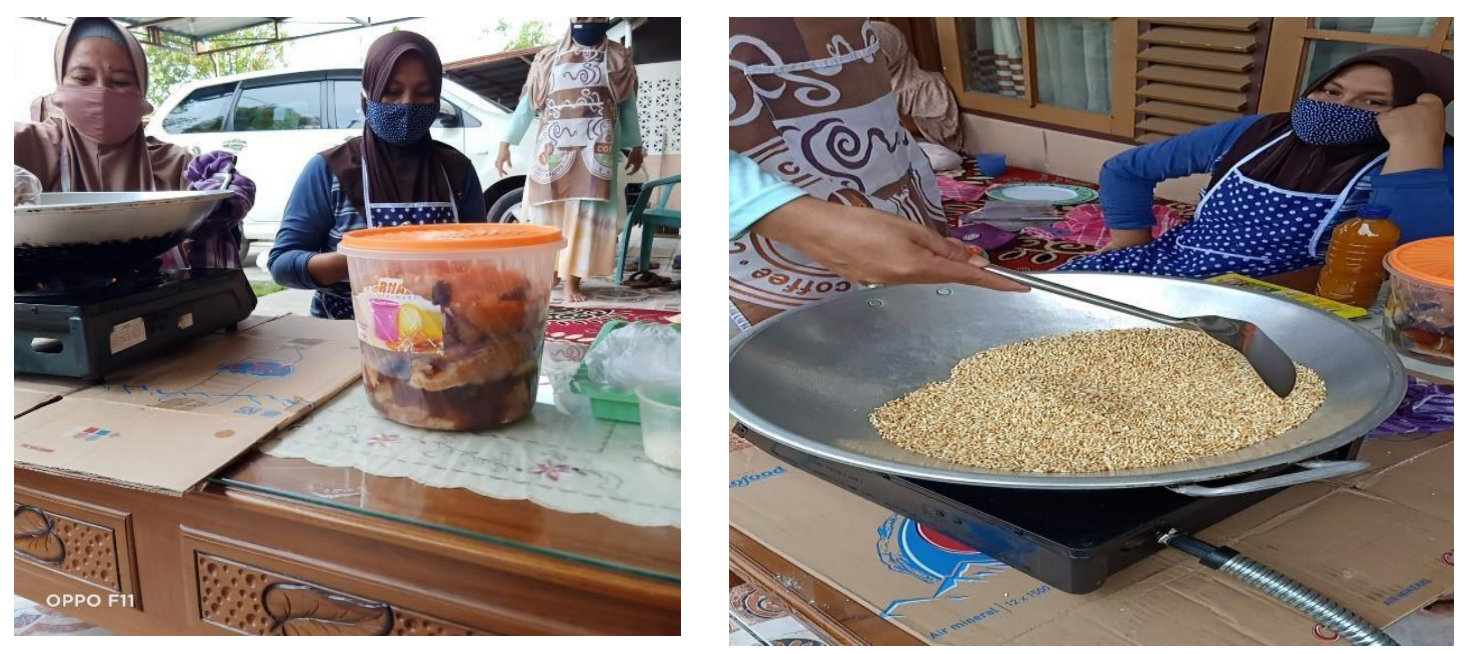

Kegiatan hari kedua diawali dengan senyum cerah ibu-ibu rumah tangga yang akan melaksanakan proses perwadian. Beras yang telah berwarna coklat kemudian di blender sampai halus. Sebagian ibu-ibu mengeluarkan ikan patin dari dalam toples yang telah ditutup selama 12 jam dan kemudian ditiriskan.
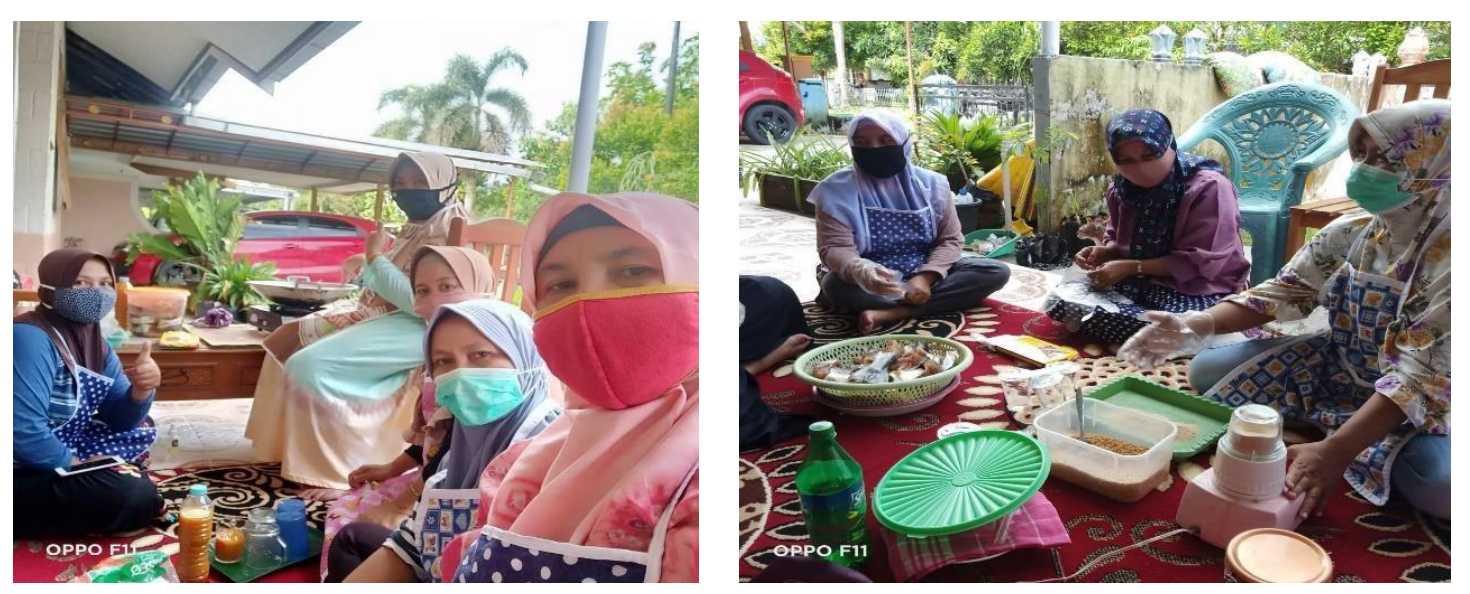

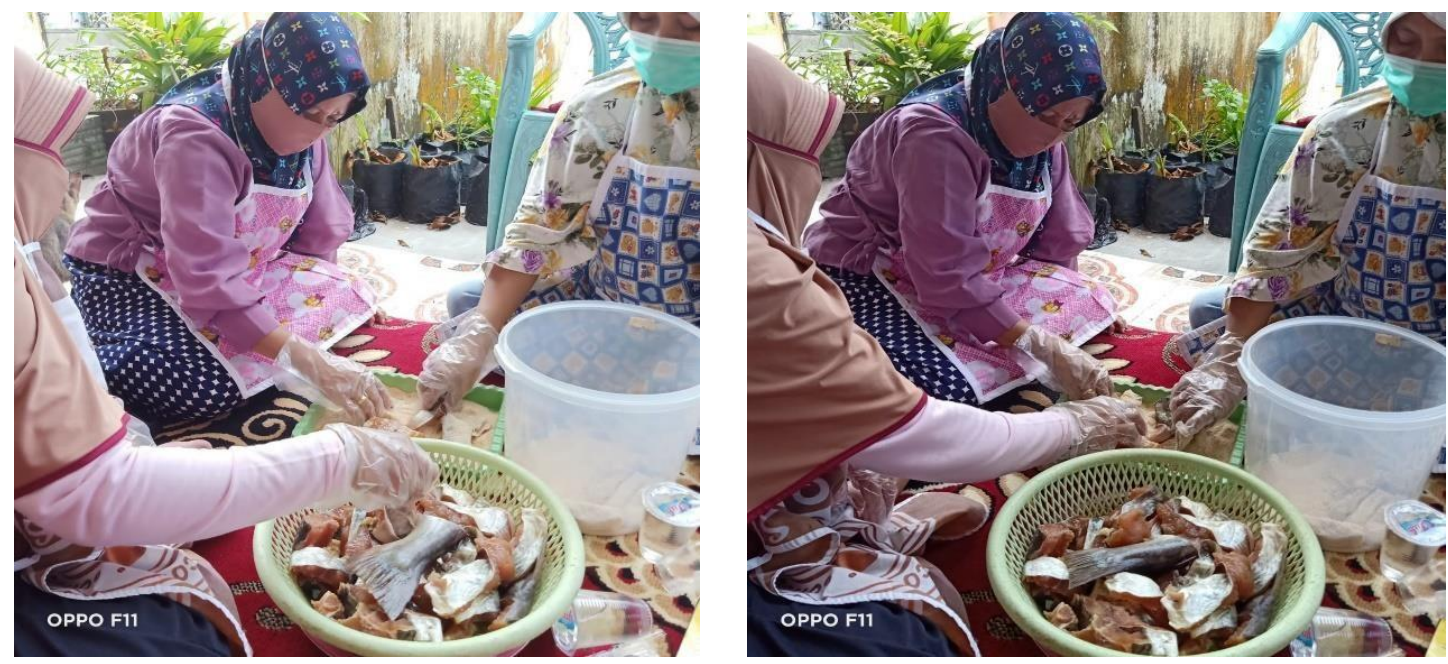

Proses setelah ikan patin ditiriskan adalah membaluri/melumuri ikan patin tadi dengan beras yang telas selesai di blender. Langkah selanjutnya setelah semua ikan patin dilumuri/dibaluri dengan beras kemudian ikan patin dimasukkan dalam toplestoples yang telah disiapkan dan ditutup rapat minimal 7 hari. Setelah 7 hari, ikanikan tersebut dimasukkan dalam toples kemasan dan siap di jual melalui online via Whatsapp, FB, dan lain-lain.
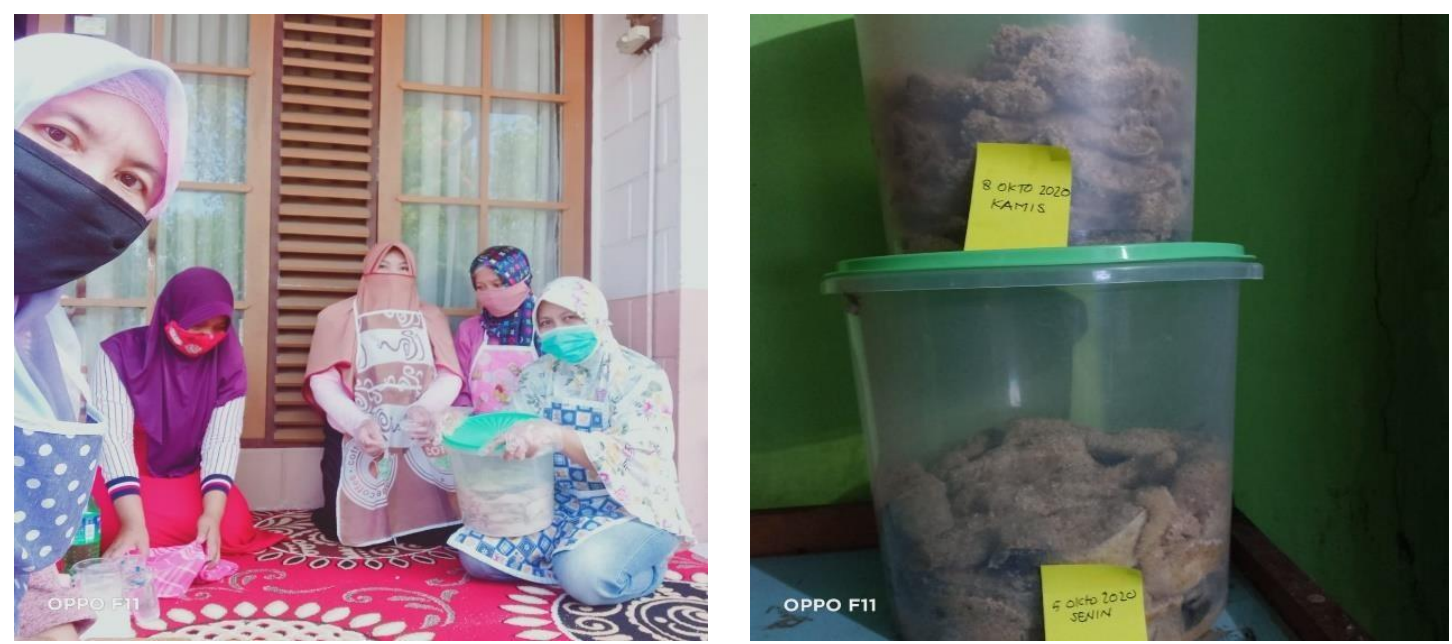
Nomor : 01

Bulan : Januari

Tahun : 2021

http://ejurnal.pps.ung.ac.id/index.php/AKSARA/index
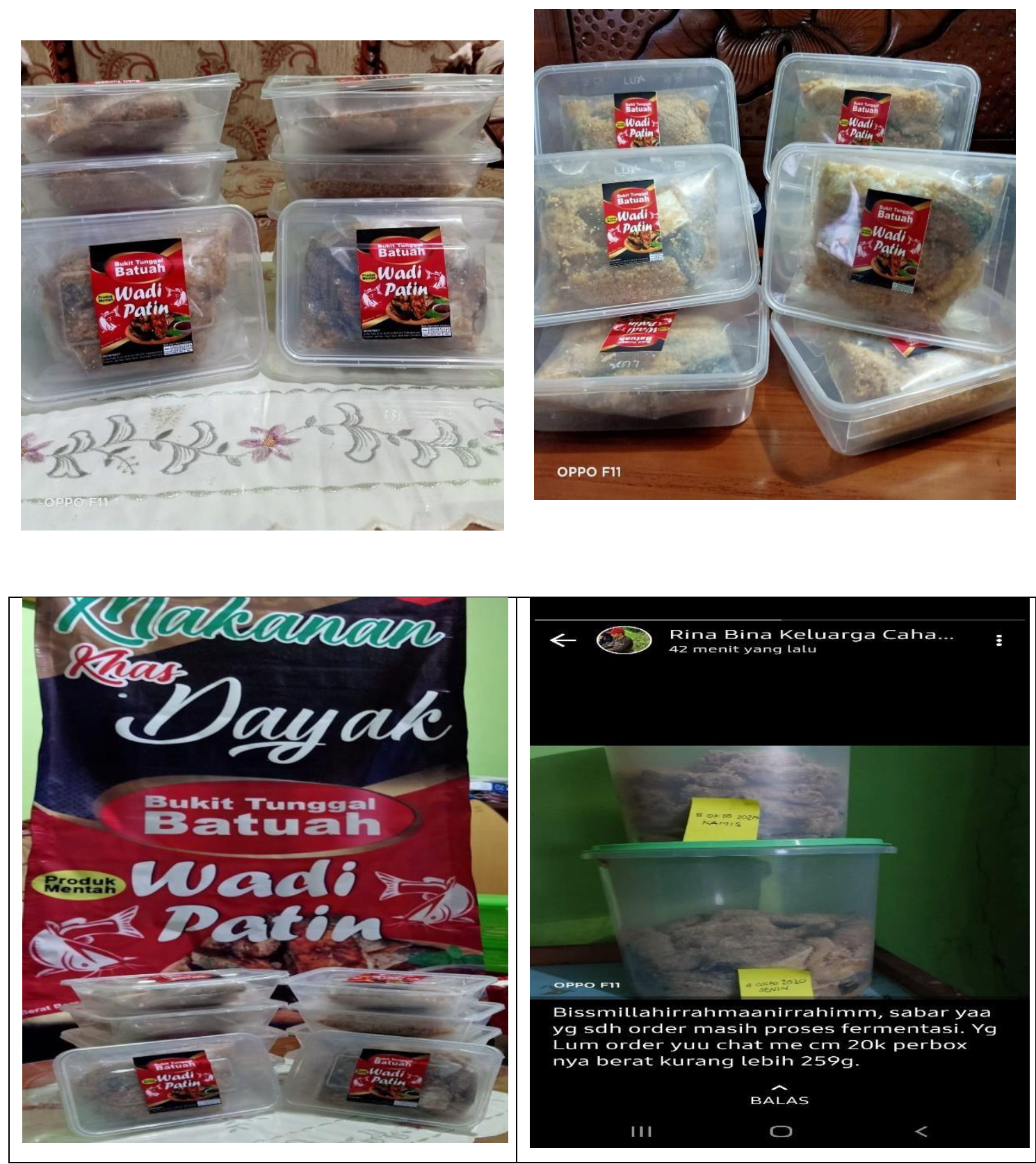

Luaran PkM yang di capai

Luaran dari kegiatan Pengabdian kepada Masyarakat (PkM) ini berupa publikasi jurnal, publikasi media massa, dan dapat dijadikan sebagai salah satu referensi mata kuliah, diantaranya adalah: Kewirausahaan dan Social Entrepreneurship, Andragogi dalam Pendidikan Masyarakat, Kajian Pemberdayaan Masyarakat di Daerah Gambut dan Aliran Sungai (DAS). 


\section{PENUTUP}

\section{Kesimpulan}

a. Motivasi ibu-ibu rumah tangga dalam melaksanakan kegiatan membuat wadi patin sangatlah luar biasa dan juga mendatangkan rejeki bagi mereka di saat pandemic covid 19 saat ini.

b. Penggunaan media sebagai salah satu bentuk promosi dan penjualan hasil wadi patin yang telah dilakukan oleh ibu-ibu rumah tangga ini sangatlah membantu sekali sehingga banyak konsumen yang memesan wadi patin ini sebagai salah satu makanan favorit.

c. Kegiatan membuat wadi patin ini dapat memupuk jiwa entrepreneurship dari ibuibu rumah tangga dan membuat mereka semakin survive.

\section{Saran}

a. Kegiatan ini dapat dilakukan dalam lingkup yang lebih luas lagi, semisal di tingkat kelurahan dan atau kecamatan agar masyarakat menjadi survive dan tahan banting di saat pandemic seperti saat ini.

b. Diujicobakan varian rasa dari wadin semisal menambahkan coklat atau ekstrak buah- buahan sebagai salah satu bentuk inovasi rasa dari wadi itu sendiri.

c. Dukungan penuh dari pemerintah dan dinas terkait sangat dibutuhkan pada kelompok- kelompok seperti ini sebagai salah satu kader penggerak di masyarakat.

\section{DAFTAR PUSTAKA}

Anwar. (2007). Manajemen Pemberdayaan Perempuan (Perubahan Sosial melalui Pembelajaran Vocational Skill pada Keluarga Nelayan). Bandung: Alfabeta.

Arief, Giri Maulana dan Heppy Millianyani. (2015). Pengaruh Social Media Marketing Melalui Instagram Terhadap Minat Beli Konsumen Sugar Tribe. FakultasEkonomi dan Bisnis Universitas Telkom

Gunawan, D.D and Huarng, H.K. (2015). Viral Effects of Social Network and Media on Consumer's Purchase Intention. Journal of Business Research, 2015, vol. 68 , issue $11,2237-2241$.

Ife, J. (1995), Community Development. New York: Macmillan Publishing Company.

----- dan Tesoriero, F. ( 2008). Alternatif Pengembangan Masyarakat di Era Globalisasi.

Community Development. Yogyakarta: Pustaka Pelajar.

Kshetri, Anita and Bidyanand Jha. (2016). "Online Purchase Intention : A Study of Automobile. Sector in India” Rev. Integr. Bus. Econ. Res. Vol. 5 No.3, p.3559. 
Naqiyah, N. (2005). Otonomi Perempuan. Malang: Bayu

Publishing.

Knowles, M. et.al (1984). Andragogi in Action: Applying Modern Principles of Adult Learning. San Fransisco: Jossey-Bass Inc.

Knowles, M. (1977). The Modern Practice of Adult Education, Andragogy Versus Pedagogy. New York: Assosiation Press.

Kotler and Keller. (2016). Marketing Management. Pearson: Prentice hall Mulyana, E. (2007). Model Tukar Belajar (Learning Exchange) dalam Perspektif Pendidikan Luar Sekolah (PLS). Bandung: Mutiara Ilmu.

Sastropoetro, S. (1988). Partisipasi, Komunikasi, Persuasi dan Disiplin Dalam Pembangunan Nasional. Bandung: Alumni.

Suharto, E. (2006). Membangun Masyarakat Memberdayakan Masyarakat, Kajian Strategis Pembangunan Kesejahteraan Sosial \& Pekerjaan Sosial. Bandung: PT. Refika Aditama 